\title{
Isolasi cendawan endofit pada tanaman padi serta potensinya sebagai pemacu pertumbuhan tanaman
}

\author{
Isolation of endophytic fungi from rice and its role as plant growth promoting \\ Hermanu Triwidodo ${ }^{1}$, Listihani $^{2}$ dan Dewa Gede Wiryangga Selangga ${ }^{3 *}$ \\ ${ }^{1}$ Departemen Proteksi Tanaman, Institut Pertanian Bogor. \\ J1. Kamper Kampus IPB Dramaga, Bogor, Jawa Barat Indonesia \\ ${ }^{2}$ Program Studi Agroteknologi, Fakultas Pertanian, Universitas Mahasaraswati Denpasar \\ J1. Kamboja No.11A, Dangin Puri Kangin, Kec. Denpasar Utara, Kota Denpasar, Bali 80233 \\ ${ }^{3}$ Program Studi Agroteknologi, Fakultas Pertanian, Universitas Warmadewa \\ Jl. Terompong No.24, Sumerta Kelod, Kec. Denpasar Tim., Kota Denpasar, Bali 80239 \\ *Email korespondensi: dewanggaselangga@gmail.com.com/HP. 081227175626
}

Diterima: 06 Maret 2021 / Disetujui: 08 Juni 2021

\begin{abstract}
Studies on endophytic fungi have been increasing recently due to its potency to promote plant growth and induce plant tolerance to pests and diseases. The research was undergone to isolation and evaluation of endophytic fungi from rice in Bali. Isolation of endophytic fungi was based-on a surface-sterilized method using alcohol and NaOCl on PDA media. More than 15 isolates were successfully isolated and the selected isolates were subjected to in vitro assay for their ability to produce antibiotics and promote plant growth. The result showed 3 isolates from midrib, 3 isolates from stem, and 1 isolate from leaves of nonpathogenic endophytic fungi had plantgrowth activities. The result of endophytic fungi identification, showed isolates from midrib and stem rice namely Phoma sp., isolates from leaves namely Acremonium sp.. This indicated that some of the nonpathogenic endophytic fungi have the potency as an inducer of plant growth.
\end{abstract}

Keywords: Acremonium, endophytic fungi, rice, Phoma sp.

\section{ABSTRAK}

Cendawan endofit banyak mendapat perhatian karena potensinya dalam memacu pertumbuhan dan kemampuannya dalam meningkatkan ketahanan tanaman terhadap penyakit dan hama tanaman. Penelitian ini bertujuan mengisolasi cendawan endofit pada tanaman padi di Bali dan menguji potensinya sebagai pemacu pertumbuhan tanaman. Isolasi bakteri endofit dilakukan dengan metode sterilisasi permukaan dengan alkohol dan natrium hipoklorit pada medium PDA. Lebih dari 15 isolat cendawan endofit berhasil diisolasi dan dikoleksi dari beberapa bagain tanaman padi. Isolat tersebut diseleksi untuk melihat kemampuan antibiosisnya terhadap cendawan patogen secara in vitro dan memacu pertumbuhan tanaman. Hasil seleksi menunjukkan cendawan endofit yang memacu pertumbuhan tanaman yaitu 3 isolat asal pelepah, 3 isolat asal batang, dan 1 isolat asal daun padi. Hal ini mengindikasikan bahwa beberapa cendawan endofit non patogen asal padi berpotensi sebagai pemacu pertumbuhan tanaman.

Kata kunci: Acremonium, cendawan endofit, padi, Phoma sp.

\section{PENDAHULUAN}

Tanaman padi merupakan komoditas yang sangat strategis dan memegang peranan penting bagi kehidupan masyarakat Indonesia sebagai bahan utama pangan. Peningkatan produksi padi terus ditingkatkan untuk memenuhi kebutuhan pangan yang terus meningkat. Namun demikian, segala upaya untuk meningkatkan produksi selalu mendapat gangguan, baik berupa cekaman biotik maupun abiotik. Cekaman abiotik antara lain berupa kekeringan, banjir atau keracunan, sedangkan cekaman biotik meliputi serangan hama dan penyakit tanaman (Suwarno, 2010).

Upaya-upaya sudah dilakukan untuk meminimalisir penggunaan fungisida sintetik yang dapat mencemari lingkungan. Pengendalian fisik seperti pengendalian hayati terhadap benih, penggunaan varietas resisten dan perlakuan panas sudah dilakukan secara intensif. Pengendalian hayati saat ini sangat dibutuhkan oleh masyarakat untuk meminimalisir ledakan pathogen dan hama yang disebabkan oleh resistensi terhadap pestisida sintetis (Wilia et al. 20120). Pengendalian hayati saat ini banyak dikembangkan, salah satunya penggunaan cendawan endofit. cendawan endofit adalah cendawan yang hidup dalam jaringan tanaman tanpa menunjukkan gejala (Seghers et al. 2004). Potensi cendawan endofit cukup besar untuk dikembangkan sebagai agens pengendali hayati, karena cendawan ini hidup dalam jaringan tanaman sehingga berperan langsung dalam menghambat perkembangan patogen dalam tanaman (Niere 2002), dan meningkatkan pertumbuhan tanaman. 
Cendawan endofit merupakan cendawan yang hidup dan berasosiasi dengan jaringan tanaman tanpa menimbulkan suatu gejala penyakit pada tanaman tersebut. Dilaporkan bahwa keberadaan cendawan endofit di dalam jaringan tanaman selain berperanan dalam perbaikan pertumbuhan tanaman (plant growth promotion), juga karena kemampuannya menghasilkan zat pemacu tumbuh, memfiksasi nitrogen, memobilisasi fosfat, dan juga berperanan dalam kesehatan tanaman (plant health promotion). Cendawan endofit diduga mampu meningkatkan sistem pertahanan tanaman terhadap gangguan penyakit tanaman karena kemampuannya untuk memproduksi senyawa antimikrob, enzim, asam salisilat, etilena dan senyawa sekunder lainnya yang berperanan menginduksi ketahanan tanaman (Backman dan Sikora 2008).

Oleh karena itu, penelitian ini bertujuan mendapatkan isolat cendawan endofit dari beberapa bagian tanaman padi yang berasal dari Bali, serta menguji kemampuannya dalam memacu pertumbuhan tanaman padi.

\section{BAHAN DAN METODE}

\section{Isolasi dan Eksplorasi Cendawan Endofit}

Sampel diambil dari tanaman padi di Subak Telun Ayah, Desa Tegalalang, Gianyar, Bali. Isolasi cendawan endofit dilakukan pada bagian tanaman. Metode isolasi cendawan endofit mengikuti metode Rodrigues (1994) yang dimodifikasi. Sterilisasi bagian tanaman dilakukan secara bertahap dengan merendam selama 60 detik dalam etanol $70 \%, \mathrm{NaOCl} 3 \%$ selama 60 detik, dan etanol $70 \%$ selama 30 detik. Setelah itu, dibilas sebanyak empat kali dengan aquades steril dikeringkan di atas kertas saring steril. Bagian tanaman dipotong kecil untuk ditumbuhkan dalam media PDA ( $\mathrm{pH} 4,5$ sampai 5,6). Hasil isolasi cendawan endofit tidak dapat digunakan jika pada media uji kesterilan masih tumbuh cendawan.

Cendawan yang tumbuh dari dalam jaringan tanaman dan telah melalui uji kesterilan dimurnikan dalam media PDA dan dibuat koleksi biakan. Isolat-isolat tersebut diidentifikasi berdasarkan warna koloni dan morfologi secara mikroskopik dan dibandingkan dengan bantuan kunci Domsch dan Gams (1980), dan Barnet dan Hunter (1998).

\section{Penetapan Cendawan Endofit Nonpatogen dan Potensinya}

Sifat nonpatogen dari cendawan endofit ditetapkan berdasarkan uji pengaruh cendawan endofit terhadap benih padi secara in vitro. Sterilisasi permukaan benih padi dilakukan dengan merendam buah dalam air steril selama 15 menit dan $\mathrm{NaOCl} 1 \%$ selama 2 menit, membilasnya dengan air steril 2 kali. Setelah itu, benih dikecambahkan pada biakan murni cendawan endofit umur 4-7 hari pada medium PDA. Pengamatan dilakukan dengan mengukur tinggi tajuk dan panjang akar pada 14 hari setelah tanam. Penelitian cendawan nonpatogen yang memacu pertumbuhan ditentukan dari respons benih setelah diberi perlakuan cendawan endofit. Cendawan pemacu pertumbuhan adalah cendawan yang memiliki kemampuan meningkatkan tinggi tanaman dan panjang akar dan mengakibatkan tanaman dapat menyerap nutrisi dengan baik dan lebih vigor.

\section{Uji Pertumbuhan}

Benih padi disterilisasi permukaan selanjutnya direndam dalam larutan cendawan endofit yang telah dimurnikan, kemudian disemai pada tray yang telah diisi tanah. Jika benih yang ditanam tidak mampu tumbuh berarti suspensi cendawan endofit tidak berpengaruh terhadap pertumbuhan tanaman padi.

\section{Pengamatan}

Frekunesi isolat cendawan yang didapatkan dari hasil isolasi dihitung frekuensinya. Rumus untuk menghitung frekuensi sebagai berikut:

$$
\text { Frek } A=\frac{\text { Isolat cendawan } A}{\text { Total potongan sample (12) }} \times 100 \%
$$

Pengamatan dilakukan terhadap morfologi isolat cendawan endofit yang didapatkan. Isolat yang mempunyai potensi memacu pertumbuhan bibit padi kemudian diidentifikasi dengan bantuan kunci identifikasi Watanabe (2002). Melihat pengaruh isolat cendawan endofit terhadap pertumbuhan tanaman.

\section{HASIL DAN PEMBAHASAN}

\section{Frekuensi Isolat}

Hasil penelitian menunjukkan terdapat beberapa isolat yang ditemukan pada masing-masing bagian tanaman diantaranya pada bagian daun terdapat 3 isolat, pada batang terdapat 3 isolat dan pada pelepah terdapat 3 isolat, sedangkan pada akar tidak didapatkan isolat. Masing-masing isolate terdiri dari 1 sampai 4 koloni (Tabel 1).

Morfologi kultur cendawan pada masing-masing bagian tanaman yang berhasil diisolasi memiliki morfologi yang berbeda-beda dari segi warna. Isolat yang didapatkan dari bagian pelepah memiliki warna putih, abu-abu dan hijau keabu-abuan (Gambar 1). Isolat yang didapatkan dari batang memiliki warna bening, hijau kecoklatan dan hijau kehitaman, sedangkan pada isolat pada bagian daun memiliki warna putih yang lebih mendominasi.

Frekuensi isolat yang diperoleh berkisar antara 8,33\% sampai $41,67 \%$. Frekuensi tertinggi pada isolat koloni hijau kehitaman yang didapatkan dari bagian batang yaitu 41,67\%, sedangkan isolat dengan frekuensi paling rendah pada Acremonium sp., hifa putih, hifa steril, Phoma, dan cendawan putih abu-abu yaitu $8,33 \%$, sedangkan isolat lainnya yaitu hifa steril dan koloni hijau kecoklatan memiliki frekuensi secara berurut-turut $16,67 \%$ dan $25 \%$. 


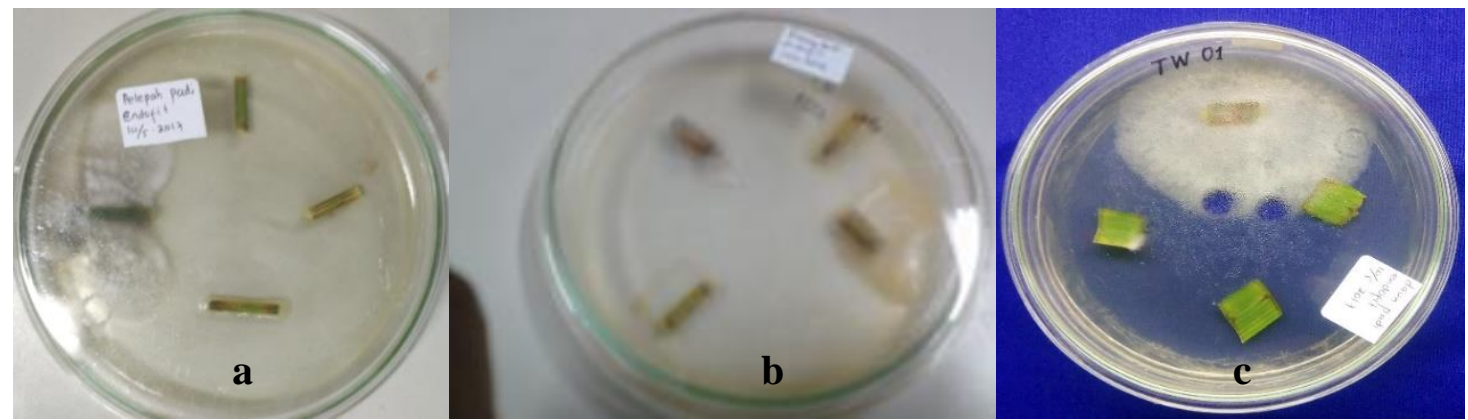

Gambar 1. Isolasi kultur cendawan pada (a) pelepah, (b) batang, dan (c) daun.

Tabel 1. Frekuensi isolat pada masing-masing bagian tanaman yang berhasil diisolasi

\begin{tabular}{llll}
\hline Bagian & Nama isolat & Jumlah & Frekuensi (\%) \\
\hline Daun & Hifa Steril 1 & 2 & 16,67 \\
& Acremonium sp. & 1 & 8,33 \\
& Hifa putih (belum di iden) 1 & 1 & 8,33 \\
\multirow{2}{*}{ Batang } & Koloni hijau kehitaman & 5 & 41,67 \\
& Koloni hijau kecoklatan & 3 & 25 \\
Akar & Hifa steril & 2 & 16,67 \\
Pelepah & Hifa steril (hijau-abu2) & - & - \\
& Phoma (hitam-abu2 ) & 1 & 8,33 \\
& Cendawan Putih Abu -abu & 1 & 8,33 \\
\hline
\end{tabular}

\section{Hasil Isolasi Cendawan Endofit}

Hasil isolasi pada pelepah padi menunjukkan warna yang berbeda pada 3 isolat yang ditemukan. Pada isolat 1 memiliki morfologi membentuk sclerotia dan berwarna hijau keabu-abuan, sedangkan pada isolat 2 memiliki morfologi mementuk sclrotia dan berwarna hitam keabu-abuan dan pada isolat 3 memiliki warna abu-abu (Gambar 2a, b, dan c).

Hasil isolasi pada batang padi menunjukkan warna yang berbeda pada 3 isolat yang ditemukan. Pada isolat 1 memiliki warna koloni hijau kehitaman, sedangkan pada isolat 2 memiliki warna hijau kecoklatan dan pada isolat 3 memiliki warna hifa steril (Gambar $2 \mathrm{~d}$, e, dan f). Hasil isolasi pada daun padi menunjukkan warna yang berbeda pada 3 isolat yang ditemukan. Pada isolat 1 memiliki morfologi membentuk sclerotia dan berwarna coklat keabu-abuan, sedangkan pada isolat 2 memiliki morfologi mementuk sclerotia dan berwarna hitam keabu-abuan dan pada isolat 3 memiliki warna orange (Gambar $2 \mathrm{~g}$, h, dan i).

Isolat cendawan endofit yang didapatkan dari tanaman padi berjumlah 9 isolat yang didapatkan pada bagian daun, pelepah dan batang padi, hal ini sejalan dengan pendapat Zakaria et al. (2010) dalam penelitiannya menunjukkan bahwa isolat cendawan endofit lebih banyak ditemukan pada bagian daun yaitu sejumlah 53 isolat pada bagian daun, 11 isolat pada bagian batang, dan 8 isolat pada bagian akar.

Rodriguez et al. (2009) menyatakan bahwa cendawan yang memiliki kisaran inang berdaun sempit pada umumnya memiliki sistem transmisi secara vertikal dan horizontal.
Sistem transmisi cendawan endofit secara vertikal melalui lapisan luar benih, benih, atau melalui bibit, sedangkan sistem transmisi cendawan endofit secara horizontal melalui spora terbawa udara (Hodgson et al. 2014).

Hal ini mengindikasikan bahwa isolat cendawan endofit lebih banyak ditemukan pada bagian daun dibandingkan isolat cendawan endofit yang lebih banyak ditemukan pada bagian akar. Penyebaran cendawan endofit secara horizontal memungkinkan cendawan endofit lebih bergerak bebas sehingga pada bagian daun memungkinkan cendawan endofit lebih banyak ditemukan dibandingkan bakteri endofit. Sistem transmisi bakteri endofit lebih mengarah pada sistem transmisi secara vertikal dan sistem invasinya ke akar terjadi secara pasif melalui lubang alami pada akar atau pada luka. Pada bagian akar biasanya didominasi oleh bakteri endofit. Hallmann (2001) menyatakan bahwa bakteri endofit telah banyak dilaporkan mengolonisasi pada berbagai bagian tanaman seperti akar, umbi, batang, daun, buah dan benih.

Benih padi yang diuji pada media PDA memiliki daya kecambah $100 \%$ pada isolat 1 , isolat 2 dan isolat 3 , sedangkan pada kontrol daya kecambah hanya $20 \%$. Perbandingan tinggi tanaman pada masing-masing isolat memiliki perbedaan yang signifikan. Isolat 1 memiliki tinggi tanaman yang paling tinggi, disusul oleh isolat 3 dan isolat 2, sedangkan kontrol memiliki tinggi tanaman yang paling rendah (Gambar 3).

Uji patogenesitas pada isolat cendawan endofit yang didapatkan dari batang menunjukkan bahwa isolat cendawan endofit yang didapatkan memiliki pengaruh terhadap 
pertumbuhan benih padi varietas IPB 3S. Pada isolat 1 , isolat 2 dan isolat 3 tidak menunjukkan infeksi patogen, namun pada kontrol hampir semua benih menunjukkan infeksi patogen yang diduga cendawan maupun bakeri patogen.

Uji patogenesitas pada isolat cendawan endofit yang didapatkan dari daun menunjukkan bahwa isolat cendawan endofit yang didapatkan memiliki pengaruh terhadap pertumbuhan benih padi varietas IPB 3S. Isolat 3 tidak menunjukkan infeksi patogen, namun pada isolat 1 dan isolat 2 menunjukkan infeksi patogen yang diduga cendawan maupun bakeri patogen.

Hasil uji patogenesitas cendawan endofit terhadap perkecambahan benih padi menunjukkan reaksi berbeda-beda, beberapa ada yang mematikan pada benih, beberapa ada yang membuat nekrotik pada kecambah dan beberapa ada yang memiliki hasil pertumbuhan yang sama pada kontrol dan bahkan beberapa isolat ada yang menunjukkan respon bahwa bakteri tersebut dapat bertindak sebagai plant growth promoting fungal (PGPF). Selain itu juga terdapat isolat cendawan endofit yang menunjukkan reaksi pada kecambah hanya menghambat perkembangan kecambah tetapi tidak menimbulkan nekrotik sehingga pertumbuhan kecambah lebih rendah dari kontrol, maka cendawan tersebut dikategorikan sebagai cendawan yang berpeluang sebagai patogen.

\section{Hasil Identifikasi}

Hasil identifikasi menunjukkan bahwa isolat 1 merupakan hifa steril, sedangkan isolat 2 dan 3 merupakan Phoma sp, (Gambar 4 a dan b). Pada hasil identifikasi isolat pada batang juga menunjukkan bahwa isolat tersebut merupakan Phoma sp (Gambar $4 \mathrm{c}$ dan d). Hasil identifikasi pada isolat daun menunjukkan bahwa isolat 1 adalah Acremonium, dan isolat 2 adalah Hifa steril (Gambar 4 e dan f).Menurut Petrini (1991), cendawan endofit adalah semua cendawan yang hidup di dalam organ tumbuhan yang sebagian atau seluruh hidupnya mengolonisasi jaringan tumbuhan secara internal tanpa mengakibatkan dampak merugikan terhadap inangnya. Stone et al. (2004) menyatakan tumbuhan tingkat tinggi dilengkapi dengan berbagai macam susunan lapisan yang menyusun struktur tubuh tumbuhan. Tumbuhan tersebut memiliki habitat beragam yang mendukung kumpulan berbagai macam spesies dari mikroorganisme. Cendawan yang merupakan salah satu komponen dominan dari kumpulan tersebut terdiri atas berbagai tipe yaitu pengkolonisasi permukaan daun dan ranting (epifit), jaringan internal dari daun (endofit daun), kulit kayu (bark endophytes), dan kayu (endofit xilem dan pengurai kayu). Hal ini sangat menarik walaupun belum jelas keterkaitannya, yaitu kolonisasi jaringan internal pada tanaman sehat oleh cendawan endofit membuka suatu wawasan baru bahwa tanaman tingkat tinggi diasumsikan seperti pelabuhan yang merupakan tempat berlabuh bagi cendawan tersebut. Stone et al. (2004) juga menyajikan perbandingan karakteristik dari cendawan endofit yang terdapat pada inang berdaun sempit dan inang berdaun lebar.
Faeth (2002) melaporkan cendawan endofit, terutama yang berada dalam fase aseksual, kolonisasinya bersifat sistemik pada rumput. Hal tersebut merupakan bentuk mutualisme tanaman, dapat dilihat dari mikotoksin cendawan endofit, alkaloid pada rumput yang terinfeksi cendawan endofit, senyawa tersebut melindungi tanaman inang dari herbivora. Rodriguez et al. (2009) juga menyatakan semua tanaman pada ekosistem alami bersimbiosis dengan cendawan endofit. Kelompok cendawan yang beragam memberikan dampak besar pada komunitas tanaman melalui peningkatan kesehatan tanaman dengan memberikan toleransi terhadap cekaman biotik dan abiotik, meningkatkan biomasa dan menurunkan konsumsi air.

Rodriguez et al. (2009) mengklasifikasikan cendawan endofit kedalam empat grup berdasarkan transmisi dan interaksi ekologinya. Endofit kelas 1 menginfeksi inang berdaun sempit, secara umum memiliki transmisi vertikal dan memproduksi mikotoksin contohnya endofit rumput Epichloe festuca dan Neotyphodium sp. Endofit kelas 2 mempunyai kisaran inang berdaun lebar dan memiliki transmisi secara vertikal dan horizontal contohnya Phoma, Colletotrichum sp., Fusarium sp., and Curvularia sp. Endofit kelas 3 dan kelas 4 menginfeksi inang berdaun lebar, memiliki transmisi horizontal dan menginfeksi tunas dan akar. Keempat kelas endofit tersebut dilaporkan dapat meningkatkan pertumbuhan dari inang dan memberikan manfaat seperti meningkatkan toleransi tanaman terhadap kekeringan. Hasil penelitian menunjukkan pada bagian pelepah daun padi, cendawan endofit yang dominan adalah Phoma hal tersebut sesuai dengan klasifikasi di atas, sehingga digolongkan pada kelas 2 karena mempunyai kisaran inang berdaun lebar seperti padi.

\section{Uji Pertumbuhan}

Hasil pengamatan pertumbuhan pada tray yaitu jumlah kecambah 5 hari setelah penanaman sebesar $46 \%$, meningkat 11 hari setelah penanaman menjadi $80 \%$ dengan rata-rata panjang bibit sebesar $1,9 \mathrm{~cm}$. Hasil uji pertumbuhan dengan perendaman benih padi pada suspensi cendawan endofit menunjukkan bahwa pertumbuhan benih lebih bagus pada perlakuan cendawan endofit dibandingkan dengan kontrol. Menurut Ho et al. (2015) dalam penelitiannya endofit Burkholderia cenocepacia 869T2 dapat menurunkan insidensi penyakit dari layu fusarium pada tanaman pisang. Tondok et al. (2012) dalam penelitiannya menunjukkan bahwa cendawan endofit mampu menginduksi ketahanan tanaman inang terhadap penyakit busuk buah pada kakao. Meskipun telah banyak penelitian mengenai mikroba endofit yang efektif dalam menekan pertumbuhan patogen dalam menyebabkan penyakit, Malinowski dan Belesky (2000) menekankan bahwa kerja endofit dalam membantu tumbuhan lebih ke arah membentuk suatu komunitas mikroba sehingga tidak sendirian dalam melindungi inangnya. Oleh karena itu, ketidakefektifan suatu mikroba endofit tidak dapat dilihat dari satu sisi saja melainkan dari berbagai faktor salah satunya adalah komunitas mikroba tersebut, diduga hal ini terjadi juga pada cendawan endofit yang diaplikasikan pada benih padi. 

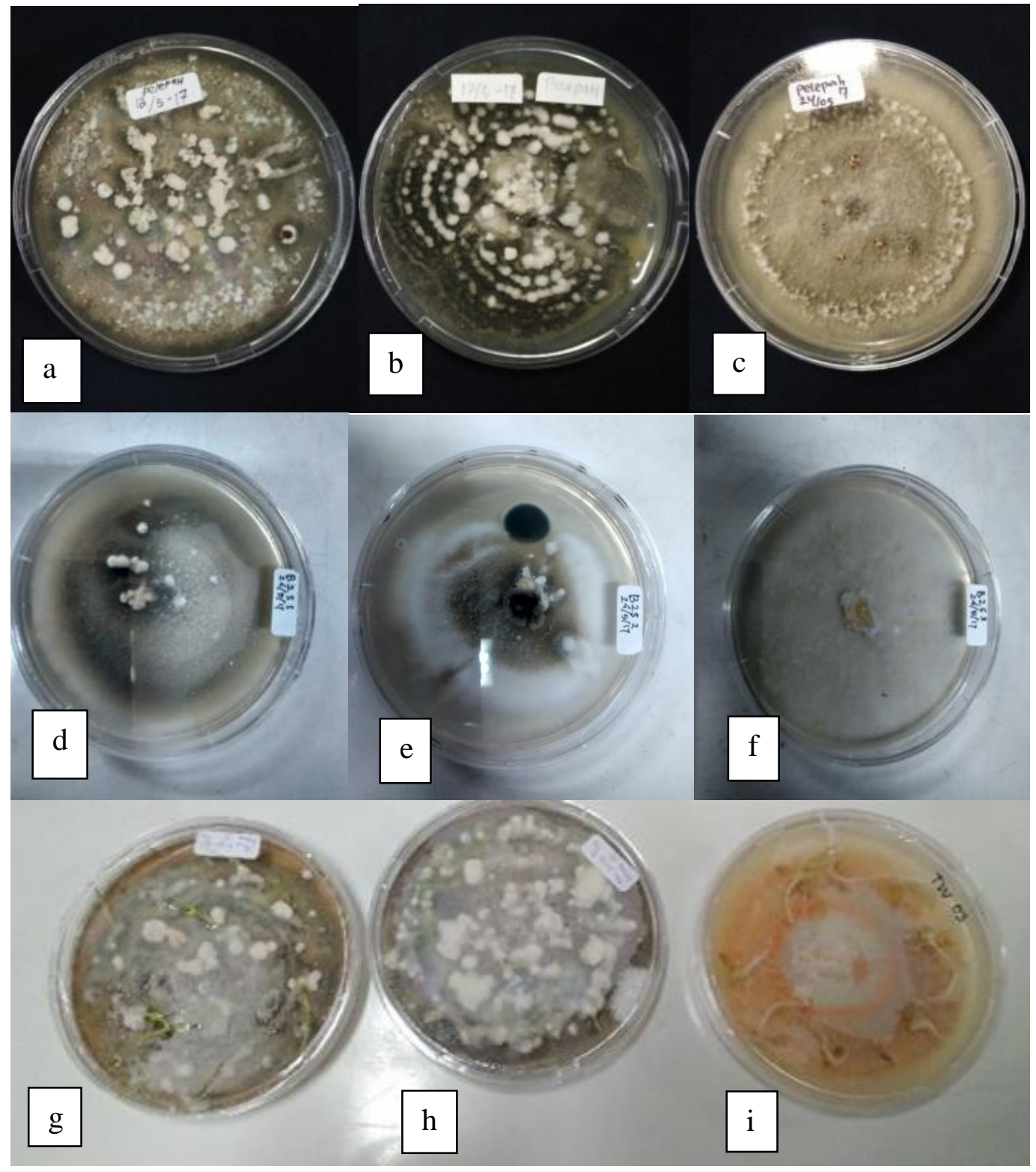

Gambar 2. Isolat dari bagian tanaman padi: pelepah padi (a-c), batang padi (d-f), dan daun padi (g-i)

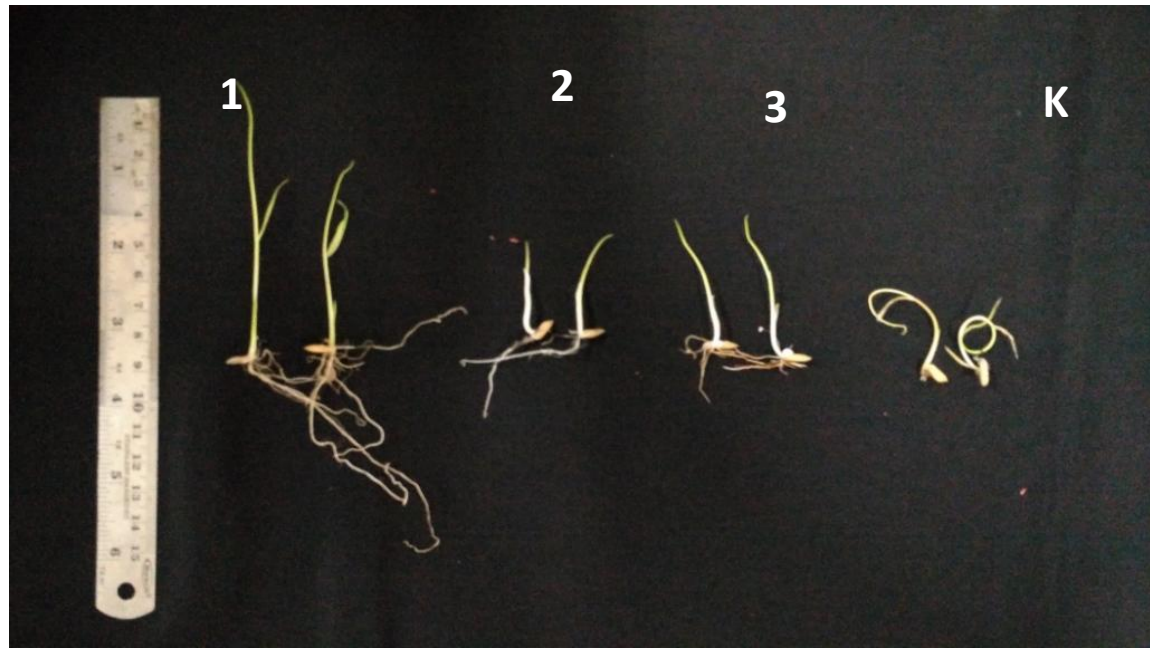

Gambar 3. Perbandingan tinggi tanaman setelah uji patogenesitas; Isolat 1, 2, 3 dan kontrol 


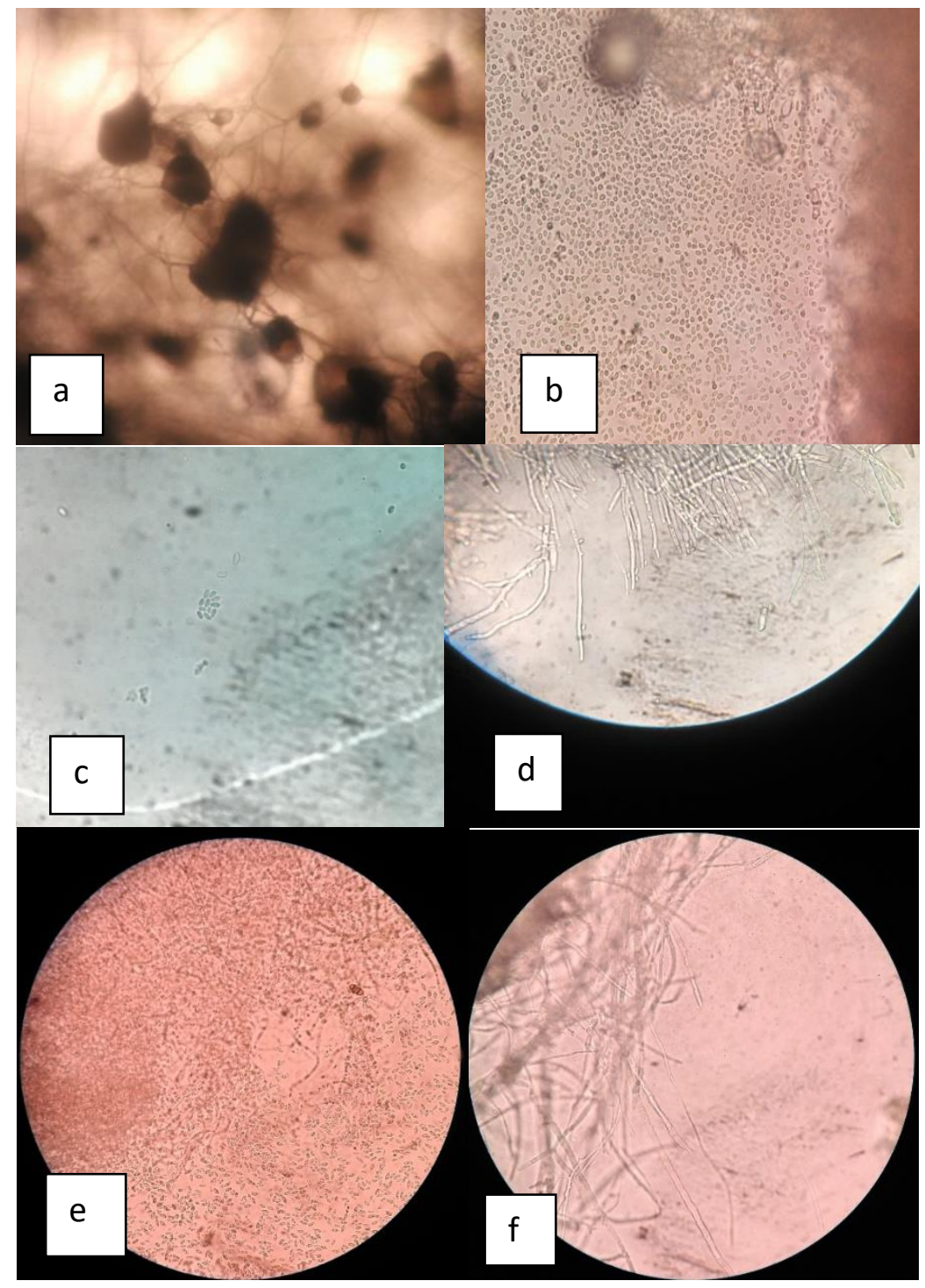

Gambar 4. Hasil identifikasi cendawan endofit: Phoma sp. pada pelepah padi (a-b), Phoma sp. pada batang padi (c-d), dan Acremonium pada daun padi (e-f)

Schulz (2006) menyatakan bahwa kolonisasi dari cendawan endofit dapat meningkatkan pertumbuhan tanaman inang. Pada penelitian ini menunjukkan benih yang diberikan perlakuan cendawan endofit memiliki perkembangan yang lebih baik dibandingkan kontrol. Schulz (2006) menambahkan bahwa ekstrak kultur dari endofit dapat meningkatkan pertumbuhan tanaman inang. Ernst et al. (2003) dalam penelitiannya menyatakan bahwa hasil isolasi cendawan endofit dari genus Stagonospora dapat meningkatkan biomassa dari alang-alang selain itu cendawan endofit ini juga dapat meningkatkan vigor dari alang-alang tersebut. Mucciarelli et al. (2002) menunjukkan pertumbuhan vegetatif tanaman peppermint secara in vitro menjadi meningkat ketika terinfeksi oleh cendawan endofit. Varma et al. (2001) dalam penelitiannya juga menunjukkan bahwa perlakuan endofit dapat meningkatkan bobot biomassa dari tanaman inang.

\section{KESIMPULAN}

Isolat cendawan endofit yang didapatkan dari tanaman padi berjumlah 9 isolat yang didapatkan pada bagian daun, pelepah dan batang padi, sedangkan pada bagian akar tidak ditemukan isolat. Pada bagian pelepah daun padi, cendawan endofit yang dominan adalah Phoma dan digolongkan pada kelas 2 karena mempunyai kisaran inang berdaun lebar seperti padi. Hasil uji pertumbuhan dengan perendaman benih padi pada suspensi cendawan endofit menunjukkan bahwa pertumbuhan benih lebih bagus pada perlakuan cendawan endofit dibandingkan dengan kontrol.

\section{UCAPAN TERIMA KASIH}

Ucapan terima kasih kepada Kepala Laboratorium 
Penyakit Tumbuhan, Universitas Udayana karena telah menyediakan alat-alat penelitian.

\section{DAFTAR PUSTAKA}

Backman, P. A., \& Sikora, R. A. (2008). Endophytes: an emerging tool for biological control. Biol Control, 46(1), 1-3.

Barnett, H. L., \& Hunter, B. B. (1998). Illustrated marga of imperfect fungi, fourth edition. USA: Prentice-Hall.

Domsch, K. H., Gams, W., \& Anderson, T. H. (1980). Compendium of soil fungi. London, UK: Academic Press.

Ernst, M., Mendgen, K. W., \& Wirsel, S.G. (2003). Endophytic fungal mutualists: seed-borne Stagonospora spp. enhance reed biomass production in axenic microcosms. Mol Plant-Microbe Interact, 16(7), 580-587.

Faeth, S. H. (2002). Are endophytic fungi defensive plant mutualists. Oikos, 98(1), 25-36.

Hallmann, J. (2001). Plant interactions with endophytic bacteria. In M. J. Jeger, \& N. J. Spence (Eds.), Biotic interaction in plant-pathogen associations (pp. 87119). London, US: CABI Publishing.

Ho, Y. N., Chiang, H. M., Chao, C. P., Su, C. C., Hsu, H. F., Guo, C. T., Hsieh, J. L., \& Huang, C. C. (2015). In planta biocontrol of soilborne Fusarium wilt of banana through a plant endophytic bacterium, Burkholderia cenocepacia 869T2. Plant Soil, 387(2), 295-306.

Hodgson, S., Cates, C., Hodgson, J., Morley, N. J., Sutton, B. C., \& Gange, A. C. (2014). Vertical transmission of fungal endophytes is widespread in forbs. Ecology and evolution, 4(8), 1199-1208.

Malinowski, D. P., \& Belesky, D. P. (2000). Adaptations of endophyte-infected cool-season grasses to environmental stresses: mechanisms of drought and mineral stress tolerance. Crop Sci, 40(4), 923-940.

Mucciarelli, M., Scannerini, S., Bertea, C. M., \& Maffei, M. (2002). An ascomycetous endophyte isolated from Mentha piperita L.: biological features and molecular studies. Mycologia, 94(1), 28-39.

Niere, B. (2002). Banana endophyte: potential for pest biocontrol. Uganda: IITA ESARC.
Petrini, O. (1991). Fungal endophytes of tree leaves. In J. A. Andrews, \& S. S. Hirano (Eds.), Microbial ecology of leaves (pp. 179-197). Springer.

Rodrigues, K. F. (1994). The foliar fungal endophytes of the Amazonian palm Euterpe oleracea. Mycologia, 86, 376-385.

Rodriguez, R. J., White, J. F, Arnold, A. E., \& Redman, R.S. (2009). Fungal endophytes: Diversity and functional roles. New Phytol, 182(2), 314-30.

Schulz, B. (2006). Mutualistic interactions with fungal root endophytes (pp. 261-279). Springer.

Seghers, D., Wittebolle, L., Top, E. M., Verstmete, W., \& Siciliano, S. D. (2004). Impact of agricultural practices on the Zea mays L. endophytic community. Appl Environ Microbiol, 70(3), 1475-1482.

Stone, J. K., Polishook, J. D., \& White, J. F. (2004). Endophytic fungi. In G. M. Mueller, G. F. Bills, \& M. S. Foster (Eds.), Biodiversity of fungi: Inventory and monitoring methods (pp. 241-270). Elsevier Academic Press.

Suwarno. (2010). Meningkatkan Produksi Padi Menuju Ketahanan Pangan yang Lestari. Pangan, 19(3), 233243.

Tondok, E. T. (2012). Keragaman cendawan endofit pada buah kakao dan potensinya dalam pengendalian busuk buah Phytophthora [Disertasi]. Bogor, ID: Institut Pertanian Bogor.

Varma, A., Singh, A., Sahay, N. S., Sharma, J., Roy, A., Kumari, M., Rana, D., Thakran, S., Deka, D., \& Bharti, K. (2001). Piriformospora indica: an axenically culturable mycorrhiza-like endosymbiotic fungus (pp. 125-150). Springer.

Watanabe, T. (2002). Pictorial atlas of soil and seed fungi, tword edition. Washington, US: CRC Pr.

Wilia, W., Hayati, I., \& Ristiyadi D. (2012). Eksplorasi Cendawan Endofit Dari Tanaman Padi Sebagai Agens Pemacu Pertumbuhan Tanaman. Program Studi Agroekoteknologi, Fakultas Pertanian Universitas Jambi, 1(4), 299-304.

Zakaria, L., Yaakop, A. S., Salleh, B., \& Zakaria, M. (2010). Endophytic fungi from paddy. Trop Life Sci Res, 21(1), 101. 